\title{
Radial Variation Studies on Wood Properties of Populus deltoides Parents and Their Hybrids
}

\author{
Hao Shen, ${ }^{a}$ Xinyi Xing, ${ }^{a}$ Ying Guan, ${ }^{\text {a,b }}$ Liang Zhou,,${ }^{a, b}$ Shengquan Liu, ${ }^{\text {a,b }}$ and Hui Gao ${ }^{\text {a,b,* }}$ \\ The radial variation and the genetic variation of wood properties between \\ the parents and offspring of Populus deltoides were studied in this work. \\ The chemical composition, density, and anatomical characteristics of \\ Populus deltoides cl. 'Danhong' and its offspring exhibited the \\ phenomenon of transgressive segregation. The chemical compositions of \\ the parents and offspring were decreased in several attributes (benzene \\ alcohol extract, hemicelluloses, lignin) with the increase of the cambial \\ age. Moreover, the fibre length, fibre width, ratio of fibre length to width, \\ and wall thickness to lumen ratio of parents and offspring were increased \\ with cambial age. In addition, the densities of parents and offspring were \\ increased with the increase of cambial age. There were significant \\ differences in wood properties among Populus deltoides and its hybrids. \\ These results indicated that Populus deltoides cl. 'Danhong' could be \\ considered as pulp material and Populus deltoides cl. 'Nanyang' as \\ building material. According to the radial variation rule of each material \\ character, the rotation cutting period can be selected as years 7 or 8 .
}

Keywords: Populus deltoides; Hybrids; Chemical composition; Density; Fibre morphology; Radial variation

Contact information: a: School of Forestry \& Landscape Architecture, Anhui Agricultural University, Hefei 230036, China; b: Key Lab of State Forest and Grassland Administration on "Wood Quality Improvement \& High Efficient Utilization”; *Corresponding author: huigaozh@163.com

\section{INTRODUCTION}

Due to its fast growth, strong adaptability, and short rotation period, poplar (Populus) is one of the most extensively cultivated species and has a high yield in the world's mid-latitude forest regions (Du et al. 2013; Jacobsen et al. 2018). The planting area of poplar in China has reached over 7 million $\mathrm{hm}^{2}$, ranking first in the world. Poplar wood is mainly used as pulp wood and plywood because its cellulose, lignin, fibre length, fibre width, and wood density are ideal pulp properties that are related to the quality of the final paper product. Thus, poplar has an important economic significance in pulp production; however, with respect to wood products, it has always been neglected (Eriksson 1990; Barnett and Bonham 2004; Marques et al. 2010; Hamzeh et al. 2011; Weng et al. 2011; Gandini and Pasquin 2012; Huang et al. 2012; Van den Bosch et al. 2015).

Crossbreeding is an important approach for poplar breeding. The hybrid offspring have 1.6 to 4.6 times better physical and chemical pulp properties, and they also have improved fibre morphology and yield compared to the pure poplar clones (Marzena et al. 2019). The quality of trees and the potential for genetic improvement should be considered when selecting forest farm tree varieties. Research on poplar parents and offspring have mainly focused on genotypes, leaf morphology, and insect pest resistance, while studies on radial variation and the law of genetic variation have been fewer, not comprehensive, and not systematic (Lippman and Zamir 2007; Chen 2010; Adebayo et al. 2011; Baranwal et 
al. 2012; Frankham 2015; Ren et al. 2017). Zhang et al. (2012) studied the genetic control of growth traits (tree height, diameter at breast height, stem volume) and wood characteristics (basic wood density and fibre length) of triploid hybrid clones of Populus, and the results showed that wood traits were more stable than growth traits. The parents and hybrid progenies of Populus deltoides have also been studied and accurate indexes of the primary wood properties have been created.

The morphological characteristics of wood, such as cellulose, lignin, density, fiber length, and microfibril angle, are closely related to the properties of pulp and paper (Parham et al.1997; Wu et al. 2011). Cellulose is not only the main component of the fiber cell wall, but also is the main component of pulp. In fact, the goal while producing chemical pulp is to remove lignin from plant fiber raw materials, while retaining cellulose and a certain amount of hemicellulose as much as possible (Georgieva et al. 2008; Forouzanfar et al. 2016). The cellulose content of raw materials directly affects the pulping yield. In addition, the arrangement of cellulose macromolecules in wood raw materials also affects the pulping yield and pulp quality (Peng et al. 2014; Sun et al. 2014; Osong et al. 2016). The longer the fiber length is, the contact sites and area between the pulp fibers also increase accordingly, and the comprehensive physical properties of the paper can be guaranteed (Fardim et al. 2012; Wu et al. 2014). Fiber width, wall thickness to lumen ratio, and ratio of lumen diameter to wall thickness are the standards of material quality. With the increase of the wall thickness to lumen ratio, paper tensile strength and burst index increase, but the tear index decreases (Stratton et al.1990; Syed et al. 2016).

Populus deltoides cl. '55/65' was introduced from the Norwest Poplar Research Institute in Yugoslavia in 1981, and the Populus deltoides cl. '2KEN8' from Italy was introduced in 1980. Both are the primary varieties of the industrial timber forest poplar in China (Zhang et al. 2008; Hu et al. 2013). The varieties (Populus deltoides cl. 'Danhong' and Populus deltoides cl. 'Nanyang') were selected by artificial pollination with Populus deltoides cl. '55/65' and Populus deltoides cl. '2KEN8' as parents. The purpose of this study was to detect the radial variation and the law of genetic variation between the parents and offspring of Populus deltoides. In this study, the effects of genetic variation on the chemical composition, density, and anatomical characteristics were determined. The radial variation of wood property indexes was also studied to determine the rotation period of mature wood.

\section{EXPERIMENTAL}

\section{Study Site}

The experimental site was located in a plantation in Jiaozuo City, Henan Province, China (north latitude $35^{\circ} 10^{\prime}-35^{\circ} 21^{\prime}$, east longitude $113^{\circ} 4^{\prime}-113^{\circ} 26^{\prime}$ ). The climate is characterized by distinct humid seasons with a temperate monsoon climate. The four seasons are distinct. The annual average temperature is 12.8 to $14.8{ }^{\circ} \mathrm{C}$. The annual average precipitation is 600 to $700 \mathrm{~mm}$. The frost-free period lasts 200 days, and there are 2200 to $2400 \mathrm{~h}$ per year of sunshine. Plantation trees were spaced with a $3 \mathrm{~m} \times 3 \mathrm{~m}$ configuration. The plantation was a monoculture and the land is flat and near roads. 


\section{Plant Material and Data Collection}

The female parent Populus deltoides cl. '55/65', the male parent Populus deltoides cl. '2KEN8', and their two hybrid offspring (Populus deltoides cl. 'Danhong' and Populus deltoides cl. 'Nanyang') were selected based on current production type, main planting variety, planting area, and growing conditions. The four specimens were all planted by the Research Institute of Forestry, Chinese Academy of Forestry, Jiaozuo, Henan province, which were harvested in 2017. The trees were 9 to 10 years of age, which better met the above conditions.

Trees with good growth and straight stems that were free of diseases and insect pests were selected for this study. Five plants were collected from each variety. Several discs were collected from the height of $1.3 \mathrm{~m}$ for each plant and air-dried. Discs were then analyzed to determine the chemical composition, main anatomical characteristics, and density of each tree. The average height of trees was between 16.7 and $19.8 \mathrm{~m}$, whereas the average diameter at breast height was between 17.2 and $20.8 \mathrm{~cm}$. In these samples, the average tree height and DBH (Diameter at Breast Height) of the female parent are the smallest.

Table 1. Basic Information of Parents and Offspring Progeny

\begin{tabular}{|c|c|c|c|c|c|}
\hline Type & $\begin{array}{c}\text { Age } \\
\text { (Year) }\end{array}$ & $\begin{array}{c}\text { Tree } \\
\text { Height }(\mathrm{m})\end{array}$ & $\begin{array}{c}\text { Diameter at } \\
\text { Breast } \\
\text { Height }(\mathrm{cm})\end{array}$ & $\begin{array}{c}\text { Genetic } \\
\text { Background }\end{array}$ & Performance growth \\
\hline $\begin{array}{c}\text { Female parent (F) } \\
\text { Populus deltoides } \\
\text { cl. '55/65' }\end{array}$ & 10 & $16.8 \pm 2.9$ & $19.6 \pm 2.3$ & $\begin{array}{c}\text { Populus } \\
\text { deltoides }\end{array}$ & $\begin{array}{c}\text { Early rapid growth, } \\
\text { excellent dry shape, } \\
\text { Asexual reproductive } \\
\text { ability }\end{array}$ \\
\hline $\begin{array}{c}\text { Male parent (M) } \\
\text { Populus deltoides } \\
\text { cl. '2KEN8' }\end{array}$ & 9 & $16.7 \pm 1.6$ & $17.2 \pm 1.2$ & $\begin{array}{c}\text { Narrow crown, } \\
\text { Populus } \\
\text { deltoides }\end{array}$ & $\begin{array}{c}\text { excellent dry shape, } \\
\text { asexual reproduction } \\
\text { ability }\end{array}$ \\
\hline $\begin{array}{c}\text { Offspring 1 } \\
\text { Populus deltoides } \\
\text { cl. 'Danhong' }\end{array}$ & 9 & $19.8 \pm 1.2$ & $20.8 \pm 0.3$ & Hybrid F1 & $\begin{array}{l}\text { Easy to survive, } \\
\text { resistant to diseases } \\
\text { and insects, excellent } \\
\text { dry shape, water and } \\
\text { humidity resistance }\end{array}$ \\
\hline $\begin{array}{c}\text { Offspring 2 } \\
\text { Populus deltoides } \\
\text { cl. 'Nanyang' }\end{array}$ & 10 & $17.4 \pm 0.7$ & $20.6 \pm 1.4$ & Hybrid F1 & $\begin{array}{c}\text { Excellent dry shape, } \\
\text { resistant to diseases } \\
\text { and insects }\end{array}$ \\
\hline
\end{tabular}

Notes: the content of tree height and DBH in the table is the average value of the 5 strains in the group is used as the test value.

Populus deltoides cl. 'Danhong' was a female plant. Under suitable site conditions, the average annual growth of DBH was as high as $6 \mathrm{~cm}$, and up to $4 \mathrm{~cm}$ under poor site conditions. Under all kinds of site conditions, it was higher than that of the parents and the control varieties. When the susceptible rate of the varieties mixed with Populus deltoides cl. 'Danhong' reached more than $90 \%$, the susceptible rate of tolerant mulberry longicorn beetles was less than 20\%. Therefore, Populus deltoides cl. 'Danhong' was basically free from mulberry longicorn beetles or susceptible, but it could not complete the life cycle and emerged as adults. Populus deltoides cl. 'Nanyang' is a male plant. The average DBH for a 6-year-old was $20.70 \mathrm{~cm}$, and the average tree height was $15.0 \mathrm{~m}$. The susceptible rate of 
the varieties mixed with Populus deltoides cl. 'Lux' was more than $45 \%$, and the mulberry longicorn beetles on southern poplar could not complete their life cycle (Zhang et al. 2008; Hu et al. 2013). Basic species information is provided in Table 1.

\section{Preparation of chemical composition samples}

Lumber discs approximately $10 \mathrm{~cm}$ thick were cut into match-stick sizes according to the rings. The 9-year-old poplars were divided into 1 to 4 years, 5 years, 6 years, 7 years, and 8 to 9 years, and the 10-year-old poplars were divided into 1 to 4 years, 5 years, 6 years, 7 years, 8 years and 9 to 10 years (Fig. 1). A total of 40- to 60-mesh samples were taken, and the raw materials were crushed and moisture balancing took place. Three samples were taken from each group for chemical composition determination, and the results were averaged.
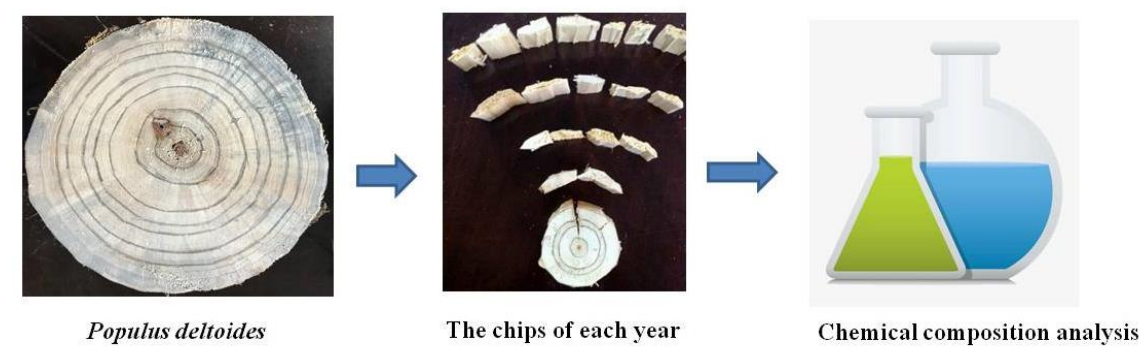

Fig. 1. The preparation process of chemical composition analysis

\section{Density sample preparation}

Lumber discs approximately $10 \mathrm{~cm}$ thick were collected. The end face of the polished disc was drawn and marked on the heartwood, the heartwood transition zone, and the sapwood. Then, the samples from three different regions (the heartwood, the heartwood transition zone, and the sapwood) were refined into $20 \mathrm{~mm} \times 20 \mathrm{~mm} \times 20 \mathrm{~mm}$ standard samples, with an accuracy of $0.01 \mathrm{~mm}$.

\section{Preparation of anatomical characteristic specimens}

The samples for anatomical properties analyses were taken from the north side of each trunk so that the growth conditions of the studied wood were as similar as possible. Age was rechecked by counting the rings from the anatomical crosscuts at breast height; the length of strips of north side and annual ring width $(\mathrm{mm})$ in the four directions (east, west, south, and north) was measured for each sample tree. Sapwood and heartwood were separated on the basis of color (Nicholls and Pederick 1979).

\section{Measurements of Chemical Composition}

The following contents were measured from the ground meal, in accordance with relative standards. The wood moisture content was determined by the gravimetric method according to the ISO 13061-1 (2014) standard. The holocellulose and $\alpha$-cellulose contents were determined using sodium chlorite, according to the standard PN-P-50092 (1992). The lignin content was determined according to the TAPPI T222 om-02 (2011) standard, and benzene alcohol extractives were determined according to TAPPI T204 cm-97 (2007). The hemicellulose contents were measured as the difference between the holocellulose content and the $\alpha$-cellulose content. 


\section{Measurements of Densities}

The density value was measured according to the ISO 13061-2 (2014) standard.

\section{Measurements of Anatomical Characteristics}

For anatomical characterization, wood macerations were conducted using glacial acetic acid and $30 \%$ hydrogen peroxide $\left(1: 1\right.$ ratio) at $80{ }^{\circ} \mathrm{C}$ for $4 \mathrm{~h}$. The macerated tissue was washed in running water until the tissue was free of all acid traces; the lengths of the fibers and vessel elements were then determined. The fibers and vessel elements were observed using a depth of field microscope (Nikon ECLIPSE Ni, Nikon Corporation, Tokyo, Japan), and images were taken at 200 magnification for analysis. In total, 50 measurements were taken for fiber length. These measurements were carried out for each annual ring from the pith to the bark.

Wood cubes $\left(2 \times 2 \times 2 \mathrm{~cm}^{3}\right)$ were prepared annually along radial positions from the pith to the bark. The wood blocks were softened by boiling in water with a microwave oven for approximately 15 to $20 \mathrm{~min}$. Transverse, radial, and tangential microscopic sections (approximately 25-30 m thick) were prepared with a rotary microtome Leica RM 2265 (Wetzlar, Germany). The sections were stained with safranin (5\%) for approximately one minute, dehydrated with an ethanol series $(50 \%, 70 \%, 80 \%, 90 \%$, and 100\%) for a few seconds, washed with 50\% xylene and pure xylene, and mounted with a drop of Canada balsam. After drying, sections were observed using a light microscope (Nikon ECLIPSE $\mathrm{Ni}$, Nikon Corporation, Tokyo, Japan) with a DS- Ri2 camera and Image NIS 5.10 software, and images were taken at 2 and 4 magnifications for analysis. ImageJ (National Institutes of Health, Bethesda, MD, USA) was used to analyze all images. 50 measurements were taken for fiber width. These measurements were carried out for each annual ring from the pith to the bark.

Wood slices with $1 \mathrm{~mm}(\mathrm{R}) \times 10 \mathrm{~mm}(\mathrm{~T}) \times 30 \mathrm{~mm}(\mathrm{~L})$ were prepared and equilibrated for 1 week in a constant temperature and humidity chamber where the temperature was $20{ }^{\circ} \mathrm{C}$, and the relative humidity was $65 \%$. Microfibril angle was measured by X-ray diffraction XRD-3 (XD-3, Beijing Persee Instrument Co., Ltd., Beijing, China) $\mathrm{X}$-ray diffractometer (the experimental conditions: $\mathrm{Cu}$ target; $\alpha$-ray; $\lambda=0.154 \mathrm{~nm} ; 36 \mathrm{kV}$; $20 \mathrm{~mA} ; h=15 \mathrm{~min}$ ). The data were then calculated using the $0.6 \mathrm{~T}$ method (Cave 1966) with Origin 2019b software. The Nikon microscope was used to measure the fiber width, which was measured randomly by selecting 50 cells foreach ring in the tangential direction. The average fibre width was calculated from 20 vessels per slide.

\section{Statistical Analysis}

The means from the anatomical property data were calculated from the individual samples. Analysis of variance (ANOVA) was performed using SPSS 20.0 software (IBM Corp., Armonk, NY, USA) to determine whether there were any significant differences between clones. The ANOVA was followed by Tukey's tests at the 5\% significance level to compare means. Variation in traits with cambial age was fitted with a multiple linear regression equation using OriginPro 2019b (64-bit, 9.6.5.169) software (OriginLab Corporation, v.9.6.5.169, Northampton, MA, USA).

The coefficient of variation is another statistic used to measure the degree of variation among observed values in the data. It was calculated using Eq.1,

$$
\mathrm{CV}(\%)=\frac{\sigma}{X} \times 100
$$


where $\mathrm{CV}$ is the coefficient of variation, $\sigma$ is the standard deviation of the character, and $\mathrm{X}$ is the mean value of the trait.

The analysis of variance uses a linear model. The purpose of variance analysis is to find out the factors that have significant influence on the thing, the interaction between the factors, and the optimal level of significant influence factors through data analysis. The actual observed value is calculated as follows,

$$
Y_{\mathrm{ijk}}=\mu+a_{\mathrm{i}}+b_{\mathrm{j}}+e_{\mathrm{ijk}}
$$

where $Y_{\mathrm{ijk}}$ is the actual observed value, $\mu$ is the average of the population, $a_{\mathrm{i}}$ is a clonal effect, $b_{\mathrm{j}}$ is the zone group effect, and $e_{\mathrm{ijk}}$ is machine error.

Genetic parameter estimation formula is the correlation between multiple measures of a trait (degree of repeatability). An index to measure the stability of their characteristics is given by,

$$
R_{\text {clone }}=\frac{n \sigma_{g}^{2}}{n \sigma_{g}^{2}+\sigma_{e}^{2}} \times 100 \%
$$

where $R_{\text {clone }}$ is an index to measure the stability of their characteristics, $\sigma_{\mathrm{e}}{ }^{2}$ is the variance between different strains within the clone, environmental variance, $\sigma_{\mathrm{g}}{ }^{2}$ is the phenotypic variance between clones, genotype variance, and $n$ is the number of different plants in the clone.

\section{RESULTS AND DISCUSSION}

\section{Analysis of Chemical Composition and its Radial Variations of Parents and Offspring}

Radial variation analysis of chemical composition of parents and offspring

The chemical compositions of the parents and offspring are shown in Table 2. The benzene alcohol extract content of the four samples ranged from $1.31 \%$ to $1.47 \%$ (Table 2 ). The extract content of Populus deltoides cl. 'Danhong' was the lowest (1.31\%), and the male parent had the highest (1.47\%). The extract content of Populus deltoides cl. 'Nanyang' was between the parent values, while the extract content of Populus deltoides cl. 'Danhong' showed the phenomenon of transgressive segregation. This phenomenon is characterized by quantitative phenotypes across biparental recombinant inbred, backcross or even early generation segregating populations that are beyond the parental range, i.e., better than the superior parent or worse than the inferior parent (de los Reyes 2019). The difference between the offspring was only $0.09 \%$. The holocellulose contents ranged from $82.01 \%$ to $83.57 \%$ (Table 2). The holocellulose content of the female parent was the highest (83.57\%), and Populus deltoides cl. 'Danhong' was the lowest $(82.01 \%)$. The holocellulose content of Populus deltoides cl. 'Nanyang' was lower than the female parent, and higher than the male parent; however, the holocellulose content of Populus deltoides cl. 'Danhong' showed the transgressive segregation phenomenon, and the difference between the offspring was $0.49 \%$. The content of $\alpha$-cellulose ranged from $46.09 \%$ to $47.25 \%$ (Table 2). The content of the female parent was the highest $(47.25 \%)$, while the lowest content was from the male parent (46.05\%). The $\alpha$-cellulose contents from the two offspring were lower than the female parent, but higher than the male parent. The difference in the $\alpha$-cellulose content between the offspring was $0.76 \%$. The hemicellulose contents 
ranged from $35.16 \%$ to $36.46 \%$ (Table 2). The hemicellulose content from Populus deltoides cl. 'Danhong' was the lowest $(35.16 \%)$, and the female parent was the highest (36.46\%). The hemicellulose content from Populus deltoides cl. 'Nanyang' was between the parents' values, while Populus deltoides cl. 'Danhong' showed the transgressive segregation phenomenon. The difference between the offspring's hemicellulose content was $0.76 \%$. The lignin content ranged from $22.05 \%$ to $24.47 \%$ (Table 2). The lignin content was highest in the male parent $(24.47 \%)$, but the female parent was the lowest $(22.05 \%)$. The lignin contents of the two offspring were between the parents' values, and the lignin content difference between the offspring was $0.94 \%$.

Table 2. Chemical Compositions of Parent and the Offsprings (\%)

\begin{tabular}{|c|c|c|c|c|c|c|}
\hline Type & Clones & $\begin{array}{c}\text { Benzene } \\
\text { Alcohol } \\
\text { Extractive }\end{array}$ & Lignin & Holocellulose & a-Cellulose & $\begin{array}{l}\text { Hemi- } \\
\text { celluloses }\end{array}$ \\
\hline $\begin{array}{c}\text { Female } \\
\text { Parent }(F)\end{array}$ & $\begin{array}{l}\text { Populus deltoides } \\
\text { cl. '55/65' }\end{array}$ & $\begin{array}{c}1.36 \pm \\
0.23\end{array}$ & $\begin{array}{c}22.05 \pm \\
2.16 \\
\end{array}$ & $83.57 \pm 1.19$ & $\begin{array}{c}47.25 \pm \\
2.55 \\
\end{array}$ & $\begin{array}{c}36.46 \pm \\
2.70 \\
\end{array}$ \\
\hline $\begin{array}{c}\text { Male } \\
\text { Parent } \\
(\mathrm{M})\end{array}$ & $\begin{array}{l}\text { Populus deltoides } \\
\text { cl. '2KEN8' }\end{array}$ & $\begin{array}{l}1.47 \pm \\
0.14\end{array}$ & $\begin{array}{c}24.47 \pm \\
1.41\end{array}$ & $82.28 \pm 1.13$ & $\begin{array}{c}46.09 \pm \\
2.18\end{array}$ & $\begin{array}{c}35.79 \pm \\
2.16\end{array}$ \\
\hline $\begin{array}{c}\text { Offspring } \\
1 \\
\end{array}$ & $\begin{array}{l}\text { Populus deltoides } \\
\text { Cl. 'Danhong' }\end{array}$ & $\begin{array}{l}1.31 \pm \\
0.24\end{array}$ & $\begin{array}{c}22.98 \pm \\
1.63 \\
\end{array}$ & $82.01 \pm 1.88$ & $\begin{array}{c}46.15 \pm \\
2.12 \\
\end{array}$ & $\begin{array}{c}35.16 \pm \\
1.82 \\
\end{array}$ \\
\hline $\begin{array}{l}\text { Offspring } \\
2\end{array}$ & $\begin{array}{l}\text { Populus deltoides } \\
\text { cl. 'Nanyang' }\end{array}$ & $\begin{array}{c}1.40 \pm \\
0.20\end{array}$ & $\begin{array}{c}23.92 \pm \\
1.61\end{array}$ & $82.50 \pm 1.91$ & $\begin{array}{c}46.91 \pm \\
1.70\end{array}$ & $\begin{array}{c}35.92 \pm \\
1.90\end{array}$ \\
\hline
\end{tabular}

Note: The chemical composition contents in the table are benchmarked against absolutely dry wood, and the average values of the 5 strains in the group are used as test values.

The radial variation from the main chemical composition is shown in Fig. 2. The radial variation trends of the parents' benzene alcohol extract content were consistent with that of the offspring, which showed a slightly increased trend at first, but then decreased from the pith to the outside (Fig. 2a). Nault (1988) reported the same results for the content of benzene alcohol extract of Thuja plicata Donn. Lukmandaru and Takahashi (2009) reported that the benzene alcohol extract content of Tectona grandis (L.f.) decreased gradually from the pith to the outside. The radial variation trend of holocellulose content tended to be smooth from the pith to the outside, while the radial variation trend of $\alpha$ cellulose content increased gradually from the pith to the outside (Fig. $2 b$ and $2 c$ ). These results were consistent with those reported by Donata et al. (2019) and Zhou et al. (2010). The radial variation trends of the hemicellulose and lignin contents decreased gradually from the pith to the outside, and the rate of decline was slowed down for the 7- to 8-yearold plants (Fig. 2d, 2e). Xing et al. (1994) reported that the lignin content decreased gradually from the pith to the outside.

The linear coefficients of determination $\left(\mathrm{R}^{2}\right)$ of the cambial age with the $\alpha$ cellulose, hemicellulose, and lignin of parents and offspring were 0.99, 0.99, and 0.90, respectively (Fig. 2). The p-values were all less than $0.0001 . \mathrm{R}^{2}$ and $\mathrm{p}$-values showed that the content of $\alpha$-cellulose, hemicellulose, and lignin had a certain variation in the radial direction, which provided a theoretical basis for the actual production demand. 


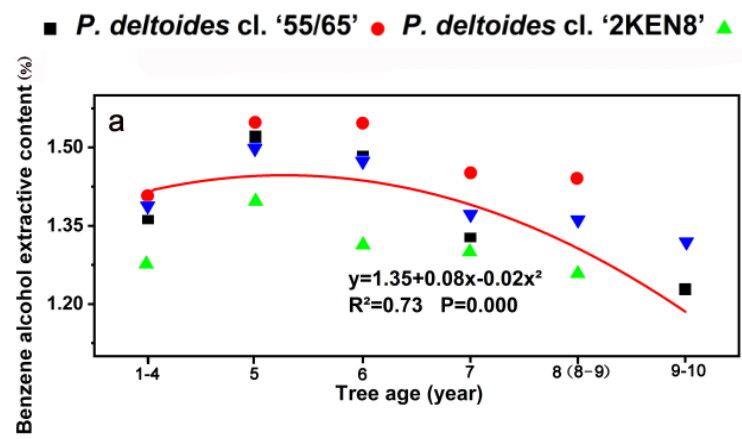

P. deltoides cl. 'Danhong' $\mathbf{P}$ P. deltoides cl. 'Nanyang'
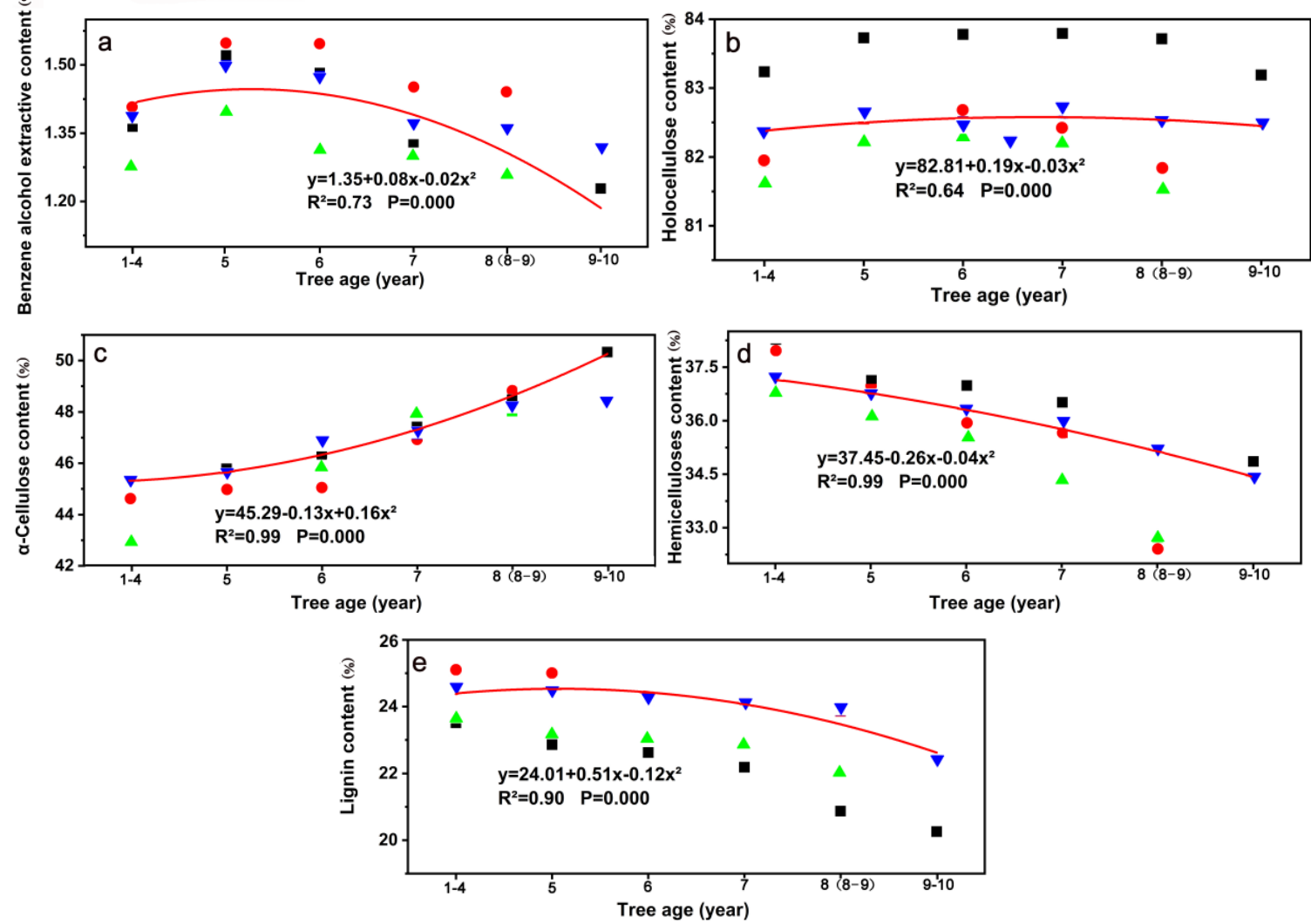

Fig. 2. Radial variation of main chemical composition: a) benzene alcohol extractive; b) holocellulose; c) $\alpha$-cellulose; d) hemicellulose; e) lignin

\section{Variance analysis of chemical components of parents and offspring}

Repeatability refers to the degree of phenotypic stability of species with the same genotype at different times or places (Zhang et al. 2003). The repeatability of the clones is an index to measure the stability of their characteristics (Yu et al. 2001). Chemical composition variance analysis of the parents and offspring are shown in Table 3 . The ratio of 0.6 to 0.7 showed strong inheritance, and 0.7 to 1 showed intense inheritance (Geyer $e t$ al. 2000). The results of the variance analysis showed that there was no significant difference in the hemicellulose contents among the four clones $(p>0.05)$, and that the growth ring had a significant effect on chemical composition ( $p<0.05)$ (Table 3$)$. It can be seen (Table 3) that the clone F-values of the benzene alcohol extract, lignin, and holocellulose were greater than that of growth rings. Therefore, the benzene alcohol extract, lignin, and holocellulose contents were greatly affected by the clones. The repeatabilities of the chemical compositions were between 0.65 and 0.85 , which was controlled by strong inheritance (Table 3 ). The growth ring F-value of $\alpha$-cellulose was greater than that of clone, indicating that the growth ring (the effect of cambial age on chemical composition characters) had a great influence on the content of $\alpha$-cellulose. The repeatability of lignin, $\alpha$-cellulose, and hemicelluloses was more than 0.80 , suggesting that traits were strongly controlled by parental genetic control. 
Table 3. Variance Analysis of Chemical Composition

\begin{tabular}{|c|c|c|c|c|c|c|c|}
\hline $\begin{array}{c}\text { Chemical } \\
\text { Composition }\end{array}$ & $\begin{array}{l}\text { Impact } \\
\text { Factor }\end{array}$ & $\begin{array}{l}\text { Sum of } \\
\text { Squares }\end{array}$ & $\begin{array}{l}\text { Degrees } \\
\text { of } \\
\text { Freedom }\end{array}$ & $\begin{array}{c}\text { Mean } \\
\text { Variance }\end{array}$ & F-value & Significance & $\begin{array}{l}\text { Repeat- } \\
\text { ability }\end{array}$ \\
\hline $\begin{array}{l}\text { Benzene- } \\
\text { alcohol- } \\
\text { extractive }\end{array}$ & $\begin{array}{c}\text { clonal } \\
\text { difference } \\
\text { growth } \\
\text { wheel } \\
\text { difference }\end{array}$ & $\begin{array}{l}1.074 \\
0.540\end{array}$ & $\begin{array}{l}3 \\
5\end{array}$ & $\begin{array}{l}0.358 \\
0.108\end{array}$ & $\begin{array}{l}8.414 \\
2.429\end{array}$ & ** & 0.68 \\
\hline Lignin & $\begin{array}{c}\text { clonal } \\
\text { difference } \\
\text { growth } \\
\text { wheel } \\
\text { difference }\end{array}$ & $\begin{array}{c}285.434 \\
92.434\end{array}$ & $\begin{array}{l}3 \\
5\end{array}$ & $\begin{array}{l}95.145 \\
18.487\end{array}$ & $\begin{array}{c}19.552 \\
3.366\end{array}$ & $\begin{array}{l}* * \\
*\end{array}$ & 0.83 \\
\hline a-Cellulose & $\begin{array}{c}\text { clonal } \\
\text { difference } \\
\text { growth } \\
\text { wheel } \\
\text { difference }\end{array}$ & $\begin{array}{c}81.346 \\
692.245\end{array}$ & $\begin{array}{l}3 \\
5\end{array}$ & $\begin{array}{c}27.115 \\
138.449\end{array}$ & $\begin{array}{c}5.802 \\
49.146\end{array}$ & $\begin{array}{l}* * \\
* *\end{array}$ & 0.84 \\
\hline Holocellulose & $\begin{array}{c}\text { clonal } \\
\text { difference } \\
\text { growth } \\
\text { wheel } \\
\text { difference }\end{array}$ & $\begin{array}{l}182.643 \\
146.705\end{array}$ & $\begin{array}{l}3 \\
5\end{array}$ & $\begin{array}{l}60.881 \\
29.341\end{array}$ & $\begin{array}{l}24.642 \\
11.299\end{array}$ & $\begin{array}{l}* * \\
* *\end{array}$ & 0.79 \\
\hline Hemicellulose & $\begin{array}{c}\text { clonal } \\
\text { difference } \\
\text { growth } \\
\text { wheel } \\
\text { difference }\end{array}$ & $\begin{array}{c}31.887 \\
591.126\end{array}$ & $\begin{array}{l}3 \\
5\end{array}$ & $\begin{array}{c}10.629 \\
118.225\end{array}$ & $\begin{array}{c}2.219 \\
38.209\end{array}$ & ** & 0.87 \\
\hline
\end{tabular}

\section{Density Analysis and Radial Variation of Parents and Offspring}

Radial variation analysis of parent and offspring density

Parent and offspring densities are shown in Table 4. Radial variation of the densities is shown in Fig. 3. The basic parents and offspring densities were 0.37 to $0.43 \mathrm{~g} / \mathrm{cm}^{3}$. The air-dry densities were 0.44 to $0.51 \mathrm{~g} / \mathrm{cm}^{3}$. The absolute dry densities were 0.42 to 0.49 $\mathrm{g} / \mathrm{cm}^{3}$ (Table 4). The basic densities, air-dry densities, and absolute dry densities of Populus deltoides cl. 'Nanyang' were the highest, while those of the male parents were the lowest. According to the variation law of densities between parents and offspring, the density value of Populus deltoides cl. 'Danhong' was between the parent values, while Populus deltoides cl. 'Nanyang' showed the transgressive segregation phenomenon. The density variations gradually increased with increased cambial age from pith to the outside (Fig. 3). These results are similar to the results of Pliura et al. (2007) and Lachenbruch et al. (2011); however, Bao et al. (2001) reported that the density of cork oak trees decreased gradually from pith to bark.

The linear coefficients of determination $\left(\mathrm{R}^{2}\right)$ of the cambial age with the basic density, air-dry density and absolute dry density of the parents and offspring were all higher than 0.84 , and the p-values were all less than 0.0001 . The density increased in varying degrees at each stage in the radial direction (Fig. 3). 
Table 4. Densities of Parent and Hybrids $\left(\mathrm{g} \cdot \mathrm{cm}^{-3}\right)$

\begin{tabular}{|c|c|c|c|c|}
\hline Type & Clones & Basic Density & Air Dry Density & $\begin{array}{c}\text { Absolute } \\
\text { Dry Density }\end{array}$ \\
\hline $\begin{array}{c}\text { Female } \\
\text { Parent (F) }\end{array}$ & $\begin{array}{c}\text { Populus deltoides cl. } \\
\text { '55/65' }\end{array}$ & $0.39 \pm 0.04$ & $0.48 \pm 0.05$ & $0.45 \pm 0.04$ \\
\hline $\begin{array}{c}\text { Male Parent } \\
\text { (M) }\end{array}$ & $\begin{array}{c}\text { Populus deltoides cl. } \\
\text { '2KEN8' }\end{array}$ & $0.37 \pm 0.03$ & $0.44 \pm 0.03$ & $0.42 \pm 0.03$ \\
\hline Offspring 1 & $\begin{array}{c}\text { Populus deltoides cl. } \\
\text { 'Danhong' }\end{array}$ & $0.38 \pm 0.03$ & $0.45 \pm 0.03$ & $0.43 \pm 0.04$ \\
\hline Offspring 2 & $\begin{array}{c}\text { Populus deltoides cl. } \\
\text { 'Nanyang' }\end{array}$ & $0.43 \pm 0.03$ & $0.51 \pm 0.04$ & $0.49 \pm 0.04$ \\
\hline Note: The densities' average values of the 5 strains in the group are used as test values. \\
\hline
\end{tabular}
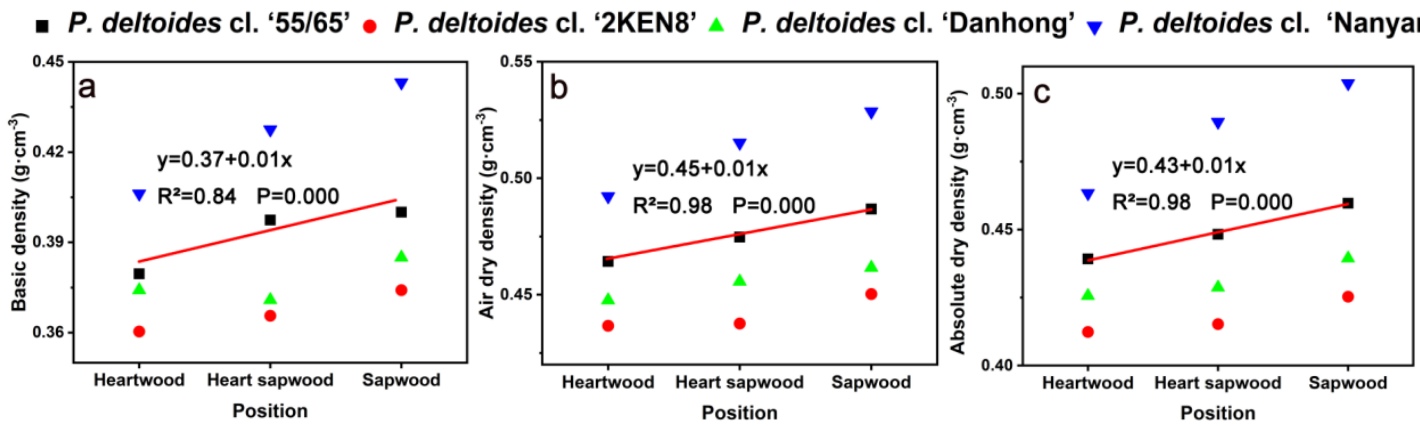

Fig. 3. Radial variation of density: a) basic density; b) air dry density; c) absolute dry density

Variance analysis of parent and offspring density

Density variance analysis is shown in Table 5. The results of the variance analysis showed that the differences between the clones and the position from the pith had a highly significant effect on wood density $(\mathrm{p}<0.01)$. From the F-values, it can be seen that the basic, air-dry, and absolute dry densities from clones were greater than that of position difference, indicating that clones had a great influence. When selecting materials, clones were the key properties of wood density considered (Table 5).

Table 5. Variance Analysis of Density

\begin{tabular}{|c|c|c|c|c|c|c|}
\hline Parameters & $\begin{array}{c}\text { Impact } \\
\text { Factor }\end{array}$ & $\begin{array}{c}\text { Sum of } \\
\text { Squares }\end{array}$ & $\begin{array}{c}\text { Degrees of } \\
\text { Freedom }\end{array}$ & $\begin{array}{c}\text { Mean } \\
\text { Variance }\end{array}$ & F-value & Significance \\
\hline Basic & Clones & 0.574 & 3 & 0.19 & 185.65 & ${ }^{* *}$ \\
Density & Position & 0.061 & 2 & 0.03 & 20.36 & ${ }^{* *}$ \\
\hline Air Dry & Clones & 0.814 & 3 & 0.271 & 188.14 & ${ }^{* *}$ \\
Density & Position & 0.045 & 2 & 0.022 & 10.35 & ${ }^{* *}$ \\
\hline Absolute & Clones & 0.743 & 3 & 0.248 & 175.42 & ${ }^{* *}$ \\
Dry Density & Position & 0.061 & 2 & 0.03 & 14.828 & ${ }^{* *}$ \\
\hline \multirow{2}{*}{ level; Indicates significant difference at $\alpha=0.01$ level; ${ }^{*}$ indicates significant difference at $\alpha=0.05$} \\
level;
\end{tabular}




\section{Anatomical Characteristics Analysis and Radial Variation of Parents and Offspring}

Radial variation of microfibril angle, fibre length, and fibre width

Radial variation of the main anatomical characteristics are shown in Fig. 4, and the values are presented in Table 6. The microfibril angle of Populus deltoides cl. 'Nanyang' was the largest $\left(17.62^{\circ}\right)$, which displayed the transgressive segregation phenomenon, and the smallest was the female parent, Populus deltoides cl. ' $55 / 65^{\prime}\left(16.52^{\circ}\right)$. The fibre lengths of the parents and offspring were 1026 to $1153 \mu \mathrm{m}$ (Table 6). The longest fibre length was Populus deltoides cl. 'Nanyang' $(1153 \mu \mathrm{m})$, which showed the transgressive segregation phenomenon. The shortest fibre length was the female parent $(1026 \mu \mathrm{m})$. The fibre widths of the parents and offspring ranged from 13.79 to $17.78 \mu \mathrm{m}$ (Table 6). The maximum fibre width was $17.78 \mu \mathrm{m}$ for Populus deltoides cl. 'Danhong', and the minimum was $13.79 \mu \mathrm{m}$ for the male parent. The microfibril angles of the parents and offspring decreased gradually with the increase of cambial age, and the decreasing speed slowed down at 7 to 8 years (Fig. 4a). The fibre length increased gradually with increased cambial age and the increasing speed slowed down slightly at 7 to 8 years (Fig. 4b). The fibre width increased gradually with the increase of cambial age, while it decreased after 7 years (Fig. 4c). Koubaa et al. (1998) reported that the fibre lengths increased gradually.

The changes in fibre length and width were related to the maturity of the tree cells. The trees near the pith were young with immature cells, and the cells divided fast and grew fast. When trees reached the maturity stage, the cells were relatively stable and divided slowly. The changes in cell length were also relatively stable and the growth rate of the trees decreased. This is the reason that the increase in fibre length and width slowed down in 7- to 8-year-old plants (Pitre et al. 2007).

The linear coefficients of determination $\left(\mathrm{R}^{2}\right)$ of the cambial age with the microfibril angle and the fibre length of the parents and offspring were 0.97 and 0.94 , respectively, and the p-values were less than 0.0001 (Fig. 4). The changes in microfibril angle and fibre length in the radial direction were the internal reasons for the properties of wood microdissection materials.

Radial variation of ratio of fibre length to width, wall thickness to lumen ratio, and ratio of lumen diameter to wall thickness

It can be seen that the ratio of fibre length to width in the parents and offspring were 63.99 to 74.46 (Table 6). The ratio of fibre length to width of Populus deltoides cl. 'Danhong' and Populus deltoides cl. 'Nanyang' were lower than their parents due to the transgressive segregation phenomenon. The largest ratio of fibre length to width was in the male parent (74.46), while the lowest ratio was in Populus deltoides cl. 'Danhong' (63.99). The wall thickness to lumen ratios were 0.26 to 0.39 , and both offspring had the transgressive segregation phenomenon (Table 6). The wall thickness to lumen ratio of Populus deltoides cl. 'Nanyang' was the largest (0.39), and Populus deltoides cl. 'Danhong' was the smallest (0.26). The ratio of lumen diameter to wall thickness was 0.73 to 0.80 , and both offspring had the transgressive segregation phenomenon (Table 6). The ratio of lumen diameter to wall thickness of Populus deltoides cl. 'Nanyang' was the smallest (0.73), while Populus deltoides cl. 'Danhong' was the largest ( 0.80$)$.

The linear coefficients of determination $\left(\mathrm{R}^{2}\right)$ of the tree age with the microfibril angle, fibre length were all higher than 0.84 , while the fibre width and ratio of fiber length to width were higher than 0.70 . The $\mathrm{R}^{2}$ value of wall thickness to lumen ratio and ratio of lumen diameter to wall thickness of the parents and offspring were only 0.27 , and the p- 
values were all less than 0.0001 . The ratio of fibre length to width increased gradually with the increase of tree age, and then decreased at the $8^{\text {th }}$ year (Fig. $4 \mathrm{~d}$ ). The wall/lumen ratio decreased at first, and then increased with the increase of tree age, and exhibited the lowest value at 7 years (Fig. 4e). The ratio of fiber lumen diameter to wall thickness increased at first, then decreased with the increase of tree age, and reached its highest at 7 years as shown in Fig. 4f.

- P. deltoides cl. ‘55/65' • P. deltoides cl. '2KEN8' $~ P$. deltoides cl. 'Danhong' $\nabla$ P. deltoides cl. 'Nanyang'
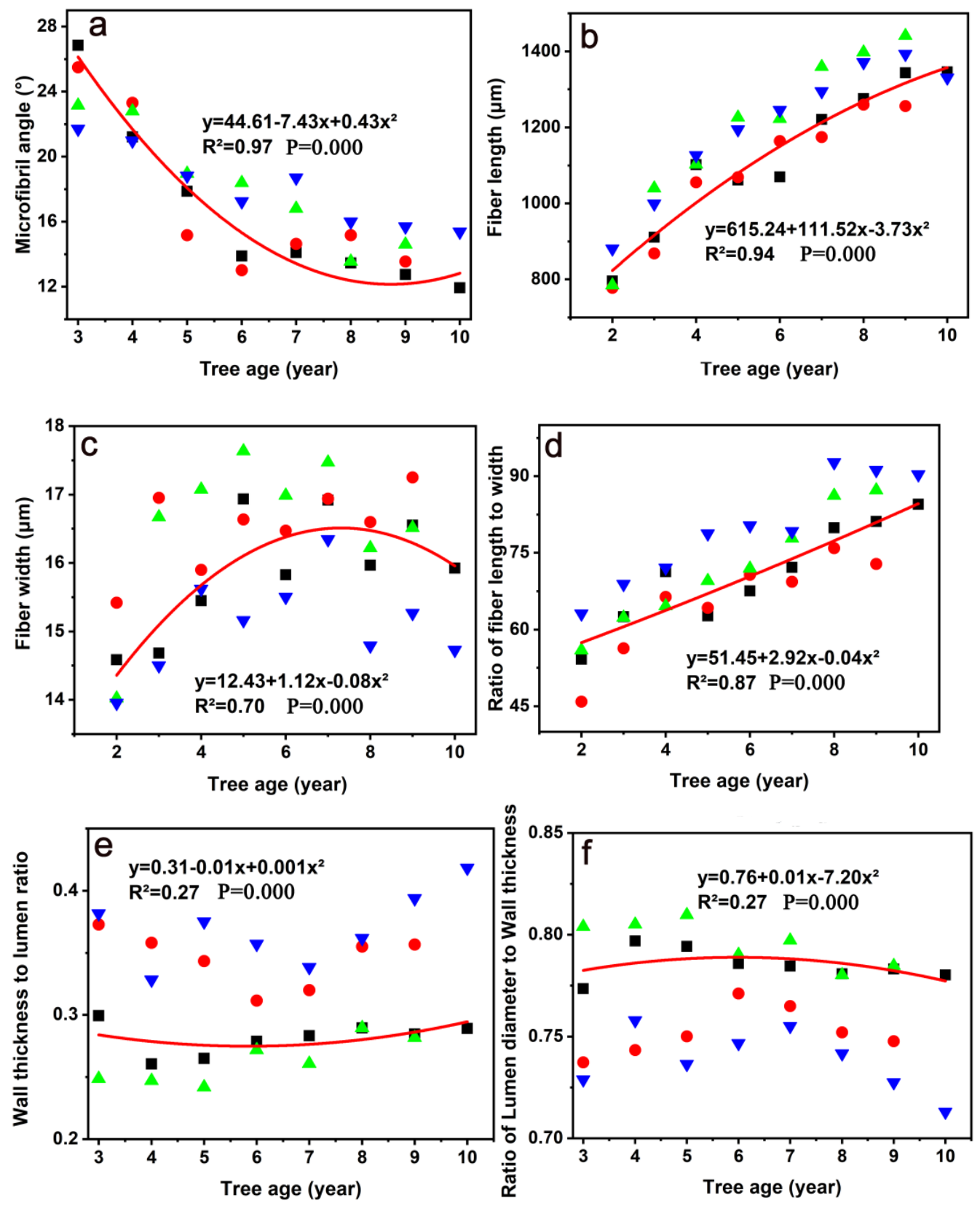

Fig. 4. Radial variation of main anatomical characteristics: a) microfibril angle; b) fiber length; c) fiber width; d) ratio of fiber length to width; e) wall thickness to lumen ratio; f) ratio of lumen diameter to wall thickness 
Table 6. Main Anatomical Characteristics of Parents and Hybrid

\begin{tabular}{|c|c|c|c|c|c|c|c|}
\hline Type & Clones & $\begin{array}{l}\text { Microfibril } \\
\text { Angle }\left({ }^{\circ}\right)\end{array}$ & $\begin{array}{l}\text { Fibre } \\
\text { length } \\
(\mu \mathrm{m})\end{array}$ & $\begin{array}{l}\text { Fibre Width } \\
\qquad(\mu \mathrm{m})\end{array}$ & $\begin{array}{l}\text { Ratio of } \\
\text { Fiber } \\
\text { Length } \\
\text { to Width }\end{array}$ & $\begin{array}{l}\text { Wall } \\
\text { Thickness } \\
\text { to Lumen } \\
\text { Ratio }\end{array}$ & $\begin{array}{l}\text { Ratio of } \\
\text { Lumen } \\
\text { Diameter } \\
\text { to Wall } \\
\text { Thickness }\end{array}$ \\
\hline $\begin{array}{c}\text { Female } \\
\text { Parent } \\
(\mathrm{F})\end{array}$ & $\begin{array}{c}\text { Populus } \\
\text { deltoides cl. } \\
\text { '55/65' }\end{array}$ & $\begin{array}{c}16.52 \pm \\
5.27\end{array}$ & $\begin{array}{c}1086.16 \pm \\
274.03\end{array}$ & $\begin{array}{c}15.95 \pm \\
2.99\end{array}$ & $\begin{array}{l}68.09 \\
\pm 3.25\end{array}$ & $\begin{array}{c}0.29 \\
\pm 0.12\end{array}$ & $\begin{array}{c}0.79 \\
\pm 0.07\end{array}$ \\
\hline $\begin{array}{l}\text { Male } \\
\text { Parent } \\
(\mathrm{M})\end{array}$ & $\begin{array}{c}\text { Populus } \\
\text { deltoides cl. } \\
\text { '2KEN8' }\end{array}$ & $\begin{array}{c}17.27 \pm \\
6.72\end{array}$ & $\begin{array}{c}1026.75 \pm \\
266.16\end{array}$ & $\begin{array}{c}13.79 \pm \\
1.60\end{array}$ & $\begin{array}{l}74.46 \\
\pm 2.67\end{array}$ & $\begin{array}{c}0.36 \\
\pm 0.11\end{array}$ & $\begin{array}{c}0.75 \\
\pm 0.06\end{array}$ \\
\hline $\begin{array}{c}\text { Offspring } \\
1\end{array}$ & $\begin{array}{c}\text { Populus } \\
\text { deltoides cl. } \\
\text { 'Danhong' }\end{array}$ & $\begin{array}{c}17.10 \pm \\
5.68\end{array}$ & $\begin{array}{c}1137.76 \pm \\
298.94\end{array}$ & $\begin{array}{c}17.78 \pm \\
2.14\end{array}$ & $\begin{array}{l}63.99 \\
\pm 3.26\end{array}$ & $\begin{array}{c}0.26 \\
\pm 0.09\end{array}$ & $\begin{array}{c}0.80 \\
\pm 0.05\end{array}$ \\
\hline $\begin{array}{c}\text { Offspring } \\
2\end{array}$ & $\begin{array}{c}\text { Populus } \\
\text { deltoides cl. } \\
\text { 'Nanyang' }\end{array}$ & $\begin{array}{c}17.42 \pm \\
6.21\end{array}$ & $\begin{array}{c}1152.90 \pm \\
262.19\end{array}$ & $\begin{array}{c}17.30 \pm \\
1.51\end{array}$ & $\begin{array}{l}66.64 \\
\pm 3.21\end{array}$ & $\begin{array}{c}0.39 \\
\pm 0.13\end{array}$ & $\begin{array}{c}0.73 \\
\pm 0.07\end{array}$ \\
\hline
\end{tabular}

The ratio of fibre length to width, the wall thickness to lumen ratio, and the ratio of fiber lumen diameter to wall thickness were related to the differentiation and growth of cells. During the process of differentiation and fibre cell growth, the cell cavity was enlarged, the cell wall thickened, and cell growth was mainly pseudo-lateral growth, which led to cell lumen enlargement and cell limited wall thickening. Because the cambium primordial cells underwent mainly pseudo-lateral growth in the process of differentiation, the fibre length increased rapidly in the transition from infancy to maturity. The fibre width (including cell cavity and cell wall thickness) increased slowly and less.

Variance of main anatomical characteristics analysis of parents and offspring

Variance analyses of the anatomical characteristics are shown in Table 7. The results indicate that the clones had a significant effect on fibre length, fibre width, ratio of fibre length to width, wall thickness to lumen ratio, and ratio of lumen diameter to wall thickness $(p<0.01)$, and had no significant effect on microfibril angle (Table 7). The effects of growth rings on the anatomical characteristics were significant $(p<0.05)$. The F-values indicated that the values of fibre width, wall thickness to lumen ratio, and ratio of lumen diameter to wall thickness for clones were greater than that for growth ring, suggesting that the fibre width, wall thickness to lumen ratio, and ratio of lumen diameter to wall thickness were greatly influenced by clones. The values of fibre length and ratio of fibre length to width for growth ring were greater than clone. The fibre length and ratio of fibre length to width were greatly influenced by growth ring. 
Table 7. Variance Analysis of Main Anatomical Characteristics

\begin{tabular}{|c|c|c|c|c|c|c|}
\hline Parameters & $\begin{array}{l}\text { Impact } \\
\text { Factor }\end{array}$ & $\begin{array}{l}\text { Sum of } \\
\text { Squares }\end{array}$ & $\begin{array}{l}\text { Degrees } \\
\text { of } \\
\text { Freedom }\end{array}$ & $\begin{array}{c}\text { Mean } \\
\text { Variance }\end{array}$ & F-value & Significance \\
\hline $\begin{array}{l}\text { Microfibril } \\
\text { Angle }\end{array}$ & $\begin{array}{c}\text { Clones } \\
\text { Growth ring }\end{array}$ & $\begin{array}{c}14.385 \\
1471.238\end{array}$ & $\begin{array}{l}3 \\
8\end{array}$ & $\begin{array}{c}4.80 \\
183.91\end{array}$ & $\begin{array}{c}0.20 \\
11.96\end{array}$ & $>\underset{* \star}{>0.05}$ \\
\hline Fiber Length & $\begin{array}{c}\text { Clones } \\
\text { Growth ring }\end{array}$ & $\begin{array}{c}22722026.03 \\
464117205.40\end{array}$ & $\begin{array}{l}3 \\
8\end{array}$ & $\begin{array}{c}7574008.67 \\
51568578.38\end{array}$ & $\begin{array}{c}99.93 \\
1757.85\end{array}$ & $\begin{array}{l}* * \\
* *\end{array}$ \\
\hline Fiber Width & $\begin{array}{c}\text { Clones } \\
\text { Growth ring }\end{array}$ & $\begin{array}{l}18304.115 \\
10049.759 \\
\end{array}$ & $\begin{array}{l}3 \\
8 \\
\end{array}$ & $\begin{array}{l}3050.68 \\
1256.22 \\
\end{array}$ & $\begin{array}{c}238.18 \\
95.14\end{array}$ & $\begin{array}{l}* * \\
* * \\
\end{array}$ \\
\hline $\begin{array}{l}\text { Ratio of Fiber } \\
\text { Length to } \\
\text { Width }\end{array}$ & $\begin{array}{l}\text { Clones } \\
\text { Growth ring }\end{array}$ & $\begin{array}{l}1217.487 \\
3537.294\end{array}$ & $\begin{array}{l}3 \\
8\end{array}$ & $\begin{array}{l}405.83 \\
442.16\end{array}$ & $\begin{array}{l}3.29 \\
7.99\end{array}$ & * \\
\hline $\begin{array}{c}\text { Wall } \\
\text { Thickness to } \\
\text { Lumen Ratio }\end{array}$ & $\begin{array}{l}\text { Clones } \\
\text { Growth ring }\end{array}$ & $\begin{array}{c}13.499 \\
1.621\end{array}$ & $\begin{array}{l}3 \\
7\end{array}$ & $\begin{array}{l}4.48 \\
0.23\end{array}$ & $\begin{array}{c}564.44 \\
24.09\end{array}$ & ** \\
\hline $\begin{array}{c}\text { Ratio of } \\
\text { Lumen } \\
\text { Diameter to } \\
\text { Wall } \\
\text { Thickness }\end{array}$ & $\begin{array}{c}\text { Clones } \\
\text { Growth ring }\end{array}$ & $\begin{array}{l}3.807 \\
0.465\end{array}$ & $\begin{array}{l}3 \\
7\end{array}$ & $\begin{array}{l}1.27 \\
0.66\end{array}$ & $\begin{array}{l}599.27 \\
25.65\end{array}$ & $\begin{array}{l}* * \\
* *\end{array}$ \\
\hline
\end{tabular}

\section{Analysis on the Overall Variation of Wood Properties between Parents and} Offspring

Analyses of the overall variation in the wood properties are shown in Table 8.

Table 8. Analysis of the Overall Variation of Wood Properties

\begin{tabular}{|c|c|c|c|c|c|}
\hline \multirow{2}{*}{ Parameters } & Mean & $\begin{array}{c}\text { Standard } \\
\text { Deviation }\end{array}$ & $\begin{array}{c}\text { Coefficient of } \\
\text { Variation (\%) }\end{array}$ & \multicolumn{2}{|c|}{ Confidence Interval at 95\% } \\
\cline { 5 - 6 } $\begin{array}{c}\text { Benzene-alcohol } \\
\text { extractive }\end{array}$ & 1.39 & 0.21 & 15.11 & 1.36 & 1.41 \\
\hline Holocellulose & 82.59 & 1.73 & 2.09 & 82.18 & 82.56 \\
\hline a-Cellulose & 46.64 & 2.21 & 4.74 & 46.40 & 46.88 \\
\hline Hemicelluloses & 35.83 & 2.20 & 6.14 & 35.49 & 35.96 \\
\hline Lignin & 23.32 & 2.39 & 10.25 & 23.06 & 23.58 \\
\hline Basic Density & 0.39 & 0.04 & 10.26 & 0.38 & 0.39 \\
\hline Air Dry Density & 0.47 & 0.05 & 10.64 & 0.46 & 0.47 \\
\hline $\begin{array}{c}\text { Absolute Dry } \\
\text { Density }\end{array}$ & 0.45 & 0.05 & 11.11 & 0.44 & 0.45 \\
\hline Microfibril Angle & 16.83 & 4.46 & 26.50 & 16.13 & 17.53 \\
\hline Fiber Length & 1101.87 & 279.58 & 25.37 & 1096.25 & 1107.49 \\
\hline Fiber Width & 16.50 & 3.43 & 20.79 & 16.46 & 16.55 \\
\hline $\begin{array}{c}\text { Ratio of Fiber } \\
\text { Length to Width }\end{array}$ & 67.79 & 12.12 & 17.88 & 63.49 & 72.09 \\
\hline $\begin{array}{c}\text { Wall Thickness to } \\
\text { Lumen Ratio }\end{array}$ & 0.31 & 0.10 & 32.26 & 0.31 & 0.32 \\
\hline $\begin{array}{c}\text { Ratio of Lumen } \\
\text { Diameter to Wall } \\
\text { Thickness }\end{array}$ & 0.77 & 0.05 & 6.49 & 0.76 & 0.77 \\
\hline
\end{tabular}


The wood properties with coefficients of variation less than $10 \%$ were holocellulose, $\alpha$-cellulose, hemicelluloses, and the ratio of lumen diameter to wall thickness within the respective $95 \%$ confidence interval, which were relatively stable and conducive to genetic control (Table 8). In the variation analysis of the material properties, the coefficient of variation of wall thickness to lumen ratio was the largest (32.26\%), while the coefficient of variation of holocellulose was the smallest (2.09\%) (Table 8).

\section{CONCLUSIONS}

1. The chemical contents (benzene alcohol extract, holocellulose, and hemicellulose) in offspring (Populus deltoides cl. 'Danhong') showed the transgressive segregation phenomenon. The density of Populus deltoides cl. 'Nanyang' showed the transgressive segregation phenomenon. Furthermore, the anatomical characteristics of the two offspring showed transgressive segregation phenomenon (except that the microfibril angle of Populus deltoides cl. 'Danhong' was between the parent values). The clones had no significant effect on the differences in hemicellulose and microfibril angle but had a significant effect on the other wood properties. The growth rings (the position from the pith) had a significant effect on the wood properties. Through the variance analyses, it can be concluded that the differences of each character between parents and offspring were different.

2. The law of radial variation showed that the radial variation of the parents was consistent with that of the offspring. At the age of 7 to 8 years, the decreasing rate of benzene alcohol extract, hemicellulose, lignin, microfibril angle, and ratio of lumen diameter to wall thickness decreased slowly, while $\alpha$-cellulose, fibre length, fibre width, ratio of fibre length to width, and wall thickness to lumen ratio increased slowly, and the density increased gradually from pith to bark.

3. In summary, the offspring of Populus deltoides cl. 'Danhong' showed the transgressive segregation phenomenon in chemical composition and anatomical characteristics, while Populus deltoides cl. 'Nanyang' showed the transgressive segregation phenomenon in density and anatomical characteristics. To select high quality germplasm resources through genetic breeding, the variability of the clones and their wood properties must be considered in the process of breeding. According to the rule of radial variation of wood properties, the rotation period can be selected in the range 7 to 8 years.

\section{ACKNOWLEDGMENTS}

This research was funded by the National Key Research and Development Program of China (No. 2017YFD0600201) and the International Science and Technology Cooperation Program of Anhui Province (1704e1002226). 


\section{REFERENCES CITED}

Adebayo, A. B., Wang, J., Cheng, Q., and DeVallance, D. (2011). "Bioenergy properties of juvenile hybrid poplars and their parent species," Wood Fiber Sci. 43(4), 412-420.

Bao, F. C., Jiang, Z. H., Jiang, X. M., Lu, X. X., Luo, X. Q., and Zhang, S. Y. (2001). "Differences in wood properties between juvenile wood and mature wood in 10 species grown in China," Wood Sci. Technol. 35(4), 363-375. DOI: 10.1007/s002260100099

Baranwal, V. K., Mikkilineni, V., Zehr, U. B., Tyagi, A. K., and Kapoor, S. (2012). "Heterosis: Emerging ideas about hybrid vigour," J. Exp. Bot. 63(18), 6309-6314. DOI: $10.1093 / \mathrm{jxb} / \mathrm{ers} 291$

Barnett, J. R., and Bonham, V. A. (2004). "Cellulose microfibril angle in the cell wall of wood fibres," Biol. Rev. 79(2), 461-472. DOI: 10.1017/s 1464793103006377

Chen, Z. J. (2010). "Molecular mechanisms of polyploidy and hybrid vigor," Trends Plant Sci. 15(2), 57-71. DOI: 10.1016/j.tplants.2009.12.003

Cave, I. D. (1966). "Theory of X-ray measurement of microfibril angle in wood," Forest Prod. J. 16(10), 37-42. DOI: 10.1007/BF00702610

de los Reyes, B. G. (2019). "Genomic and epigenomic bases of transgressive segregation - New breeding paradigm for novel plant phenotypes," Plant Sci. 288, 110213 110221. DOI: 10.1016/j.plantsci.2019.110213

Du, Q. Z., Gong, C. R., Pan, W., and Zhang, D. Q. (2013). "Development and application of microsatellites in candidate genes related to wood properties in the Chinese white poplar (Populus tomentosa Carr.)," DNA Res. 20(1), 31-44. DOI: 10.1093/dnares/dss031

Eriksson, K. E. L. (1990). "Biotechnology in the pulp and paper industry," Wood Sci. Technol. 24, 79-101. DOI: 10.1007/bf00225309

Fardim, P., Liebert, T., and Heinze, T. (2012). "Pulp fibers for papermaking and cellulose dissolution," Epnoe. 253-282. DOI:10.1007/978-3-7091-0421-79

Forouzanfar, R., Vaysi, R., Rezaei, V. T., Hosseini, S. B., and Sukhtesaraie, A. (2016). "Study on production of fluting paper from poplar pulp mixed with hardwood NSSC pulp,” J. Indian I Sci. 13(1), 55-63. DOI: 10.1007/s13196-016-0166-6

Frankham, R. (2015). "Genetic rescue of small inbred populations: Meta-analysis reveals large and consistent benefits of gene flow," Mol. Ecol. 24(11), 2610-2618. DOI: 10.1111/mec.13139

Gandini, A., and Pasquini, D. (2012). "The impact of cellulose fibre surface modification on some physico-chemical properties of the ensuing papers," Ind. Crop. Prod. 35(1), 15-21. DOI: 10.1016/j.indcrop.2011.06.015

Georgieva, N., Boeva-Spiridonova, R., Spiridonov, I., Petkova, E., and Yotova, L. (2008). "Application of improved chemical-mechanical pulp from poplar wood in the packing paper composition," Holz Roh Werkst. 66(1), 75-76. DOI: 10.1007/s00107007-0196-2

Geyer, W. A., Dewyke, J., and Walawender, W. P. (2000). "Biomass and gasification properties of young Populus clones," Wood Fiber Sci. 32(3), 375-384.

Hamzeh, Y., Ashori, A., and Mirzaei, B. (2011). "Effects of waste paper sludge on the physico-mechanical properties of high-density polyethylene/wood flour composites," J. Polym. Environ. 19, 120-124. DOI: 10.1007/s10924-010-0255-3 
Huang, H. B., Du, H. H., Wang, W. H., and Shi, J. Y. (2012). "Characteristics of paper mill sludge-wood fiber-high-density polyethylene composites," Polym. Compos. 33(9), 1628-1634. DOI: 10.1002/pc.22287

Hu, J. J., Li, M. Z., Zhao, Z. C., Sun, X. H., Li, X. L., Li, S. M., and Han, Y. F. (2013). "An elite variety of Populus deltoides 'Nanyang,", Scientia Silvae Sintcae. 49(7), 188-188. DOI: 10.11707 /j. 1001-7488. 20130728

ISO 13061-1 (2014). "Physical and mechanical properties of wood-test methods for small clear wood specimens-Part 1: Determination of moisture content for physical and mechanical tests," International Organization for Standardization, Geneva, Switzerland.

ISO 13061-2 (2014). "Physical and mechanical properties of wood - test methods for small clear wood specimens-Part 2: Determination of density for physical and mechanical tests," International Organization for Standardization, Geneva, Switzerland.

Jacobsen, A. L., Valdovinos-Ayala, J., Rodriguez-Zaccaro, F. D., Hill-Crim, M. A., Percolla, M. I., and Venturas, M. D. (2018). "Intra-organismal variation in the structure of plant vascular transport tissues in poplar trees," Trees 32, 335-1346. DOI: 10.1007/s00468-018-1714-z

Koubaa, A., Hernández, R. E., Beaudoin, M., and Poliquin, J. (1998). "Interclonal, intraclonal, and within-tree variation in fiber length of poplar hybrid clones," Wood Fiber Sci. 30(1), 40-47.

Lachenbruch, B., Moore, J. R., and Evans, R. (2011). "Radial variation in wood structure and function in woody plants, and hypotheses for its occurrence," in: Size-and AgeRelated Changes in Tree Structure and Function. Tree Physiology (Vol. 4), F. Meinzer, B. Lachenbruch, and T. Dawson (eds.), Springer, Dordrecht, Netherlands. DOI: 10.1007/978-94-007-1242-3_5

Lippman, Z. B., and Zamir, D. (2007). "Heterosis: Revisiting the magic," Trends Genet. 23(2), 60-66. DOI: 10.1016/j.tig.2006.12.006

Lukmandaru, G., and Takahashi, K. (2009). "Radial distribution of quinones in plantation teak (Tectona grandis L.f.)," Ann. Forest Sci. 66, 605-605. DOI: 10.1051/forest/2009051

Marques, G., Rencoret, J., Gutierrez, A., and del Rio, J. C. (2010). "Evaluation of the chemical composition of different non-woody plant fibers used for pulp and paper manufacturing," The Open Agriculture Journal 93(4), 93-101. DOI: 10.2174/1874331501004010093

Marzena, N., Piotr, P., Kamila, P., Marek, K., Adam, K., Tomasz, W., and Mirko, L. (2019). "Productivity, growth patterns and cellulosic pulp properties of hybrid aspen clones," Forests 10(5), Article Number 450. DOI: 10.3390/f10050450

Nault, J. (1988). "Radial distribution of thujaplicins in old growth and second growth western red cedar (Thuja plicata Donn),"Wood Sci. Technol. 22, 73-80. DOI: 10.1007/bf00353230

Nicholls, J. W. P., and Pederick, L. A. (1979). "Variation in some wood characteristics of Eucalyptus nitens," Australian Forest Res. 9(4), 309-321.

Osong, S. H., Norgren, S., and Engstrand, P. (2016). "Processing of wood-based microfibrillated cellulose and nanofibrillated cellulose, and applications relating to papermaking: A review," Cellulose. 23(1), 93-123. DOI:10.1007/s10570-015-0798-5 
Parham, R. A., Robinson, K. W., and Isebrands, J. G. (1977). "Effects of tension wood on kraft paper from a short-rotation hardwood (Populus "tristis No. 1")," Wood Sci Technol. 11(4), 291-303. DOI: 10.1007/bf00356927

Peng, X. P., Sun, S. L., Wen, J. L., Yin, W. L., and Sun, R. C. (2014). "Structural characterization of lignins from hydroxycinnamoyl transferase (HCT) down-regulated transgenic poplars," Fuel. 134, 485-492. DOI: 10.1016/j.fuel.2014.05.069

Pitre, F. E., Cooke, J. E., and Mackay, J. J. (2007). "Short-term effects of nitrogen availability on wood formation and fibre properties in hybrid poplar," Trees. 21(2), 249-259. DOI: 10.1007/s00468-007-0123-5

Pliura, A., Zhang, S. Y., MacKay, J., and Bousquet, J. (2007). "Genotypic variation in wood density and growth traits of poplar hybrids at four clonal trials," For. Ecol. Manag. 238(1-3), 92-106. DOI:10.1016/j. foreco.2006.09.082

PN-P 50092 (1992). "Surowce dla przemysłu papierniczego-drewno-analiza chemiczna [Chemical analysis of wood as raw material — papermaking industry]," Polish Committee for Standardization, Warsaw, Poland.

Ren, Y., Zhang, J., Liang, H., Wang, J., and Yang, M. (2017). "Inheritance and expression stability of exogenous genes in insect-resistant transgenic poplar," Plant Cell, Tissue and Organ Culture 130(3), 567-576. DOI: 10.1007/s11240-017-1247-y

Stratton, R. A., and Colson, N. L. (1990). "Dependence of fiber/fiber bonding on some papermaking variables," Mrs Proceedings. 197, 173. DOI: 10.1557/proc-197-173

Sun, Q., Foston, M., Sawada, D., Pingali, S. V., O’Neill, H. M., Li, H., and Ragauskas, A. J. (2014). "Comparison of changes in cellulose ultrastructure during different pretreatments of poplar," Cellulose 21(4), 2419-2431. DOI: 10.1007/s10570-0140303-6

Syed, N. F. N., Zakaria, M. H., and Bujang, J. S. (2016). "Fiber characteristics and papermaking of seagrass using hand-beaten and blended pulp," BioResources. 11(2), 5358-5380. DOI: 10.15376/biores.11.2.5358-5380

TAPPI T222 om-02 (2011). "Lignin in wood and pulp," TAPPI Press, Atlanta, GA, USA.

TAPPI T204 cm-97 (2007). "Solvent extractives of wood and pulp," TAPPI Press, Atlanta, GA, USA.

Van den Bosch, S., Schutyser, W., Vanholme, R., Driessen, T., Koelewijn, S., Renders, T., Meester, B. D., Huijgen, W. J. J., Dehaen, W., Courtin, C. M. (2015). "Reductive lignocellulose fractionation into soluble lignin-derived phenolic monomers and dimers and processable carbohydrate pulps," Energ. Environ. Sci. 8(6), 1748-1763. DOI: $10.1039 / \mathrm{c} 5 \mathrm{ee} 00204 \mathrm{~d}$

Weng, Z., Su, Y., Wang, D. W., Li, F., Du, J. H., and Cheng, H. M. (2011). “Graphenecellulose paper flexible supercapacitors," Adv. Energy Mater. 1(5), 917-922. DOI: 10.1002/aenm.201100312

Wu, S. J., Xu, J. M., Li, G. Y., Risto, V., Du, Z. H., Lu, Z. H., Li, B. Q., and Wang, W. (2011). "Genotypic variation in wood properties and growth traits of Eucalyptus hybrid clones in southern China," New Forest. 42, 35-50. DOI: 10.1007/s11056-0109235-7

Wu, Q., Chen, H. L., Wang, B. B., and Cao, B. B. (2014). “Analysis on fast-growing black poplar branch used as raw materials for APMP pulping and papermaking," Appl. Mech. Mater. 972, 448-453. DOI: 10.4028/www.scientific.net/amm.448453.972 
Xing, S. X., Zhang, Q. H., and Liu, Z. T. (1994). "Study on the chemical components and fiber dimensions of seven poplar hybrids," J. Beijing Forestry Univ. 16(1), 53-57. DOI : 10. 13332 /j . 1000 -1522. 1994. 01.008

Yu, Q., Tigerstedt, P. M. A., and Haapanen, M. (2001). "Growth and phenology of hybrid aspen clones (Populus tremula L. × Populus tremuloides Michx.)," Silva Fennica 35(1), 15-25. DOI: 10.14214/sf.600

Zhang, P., Wu, F., and Kang, X. (2012). "Genotypic variation in wood properties and growth traits of triploid hybrid clones of Populus tomentosa at three clonal trials," Tree. Genet. Genomes 8, 1041-1050. DOI: 10.1007/s11295-012-0484-9

Zhang, S. Y., Yu, Q. B., Chauret, G., and Koubaa, A. (2003). "Selection for both growth and wood properties in hybrid poplar clones," Forest Sci. 49(6), 901-908. DOI: 10.1093/forestscience/49.6.901

Zhang, C. L., Li, S. M., Zhao, Z. C., Hu, J. J., and Han, Y. F. (2008). “A new poplar variety Populus deltoides CL.'Danhong'," Scientia Silvae Sinicae. 44(1), 169.

Zhou, L., Liu, S. Q., Gao, H., Zhang. L. P. (2010). "Radial variation of chemical composition of poplar clone 107 (Populus $\times$ euramericana cv. 'Neva')," J North Univ Forestry. 38(12), 10-11. DOI: 10.1016/j.socnet.2012.07.005

Article submitted: January 26, 2021; Peer review completed: March 21, 2021; Revised version received and accepted: April 29, 2021; Published: May 17, 2021.

DOI: 10.15376/biores.16.3.4905-4923 